\title{
Vi vil ikke ha flere piller
}

\begin{abstract}
Hvem drømmer vel ikke om en enklere og mer behagelig vei ut av sykdom og lidelse? For legene kan nye medisiner og ny teknologi føre til kortere konsultasjoner og mindre press fra krevende pasienter, og for pasientene og deres pårørende vil nye piller skape store forventninger til et nytt og bedre liv.
\end{abstract}

Det var mange som fattet håp da legemiddelfirmaet Lundbeck lanserte alkoholpillen Selincro for nesten to år siden. Ifølge medieomtalen skulle denne vidunderpillen få alkoholtørste nordmenn til å miste lysten på alkohol etter noen glass, og den skulle få alkoholavhengige til å kunne drikke kontrollert (1). Endelig skulle alkoholikere og andre rusavhengige få leve et normalt liv uten å måtte takke nei til alkohol i sosiale sammenhenger. Det var nesten ikke til å tro.

\section{Legemiddelindustrien styrer informasjonen}

Når nye piller blir lansert, er det legemiddelindustrien som styrer informasjonen, godt hjulpet av smarte kommunikasjonsrådgivere og naive journalister. Påstander og argumenter slukes rått, for hvem vil vel ødelegge en gladsak?

Et legemiddelselskap kan ikke markedsføre pillene sine på vanlig måte, men industrien vet hvordan den skal nå frem til både leger og aktuelle konsumenter. Lundbeck opprettet blant annet nettsiden drikkmindre.no. På nettsiden skriver legemiddelfirmaet at det beste er å slutte å drikke, men selskapet slår samtidig fast at «totalavhold vil for mange fremstå som et drastisk tiltak og oppfattes som et mål det er umulig å holde fast ved» (2). Mon tro hvilke interesser Lundbeck har for å dyrke en slik påstand?

For de fleste handler alkoholisme minst like mye om en psykisk avhengighet som en fysisk trang til å drikke, men det perspektivet er det vanskelig å finne på nettsidene til Lundbeck (2).

\section{Uheldig markedsføring}

For en aktiv alkoholiker er alkoholen det kjæreste som finnes, og redselen for å skilles fra vinglasset eller ølboksen er stor. Håpet til mange alkoholikere er derfor å kunne drikke normalt igjen, og han eller hun vil søke all den informasjon som bygger opp under dette håpet. Hvis legemiddelindustrien og helsevesenet skal få spre holdningene om hvor vanskelig det er å si nei takk, risikerer vi at mange utsetter nødvendige grep - og i verste fall at tørrlagte alkoholikere vil prøve seg på «normal drikking» igjen. Det kan være livsfarlig.

Heldigvis har ikke omsetningen av Selincro vært så stor som legemiddelprodusenten hadde håpet. Tall fra Reseptregis- teret viser at 1614 pasienter fikk alkoholpillen i Norge i 2014 (i gjennomsnitt fikk hver pasient 23 doser), og omsetningen var på beskjedne 1,56 millioner kroner (3). Det kan skyldes den nøkterne omtalen som Legemiddelverket ga til norske leger (4).

\section{«Redselen for å skilles fra vinglasset eller ølboksen er stor»}

Men all erfaring viser at legemiddelindustrien vet å bruke virkemidler og lobbyister når salget er lavere enn forventet, så det er all grunn til å være på vakt mot nye gladsaker som målbærer den ønskede effekten.

\section{Avholdenhet er den eneste løsningen}

Pillene sitter løst blant mange av landets fastleger. Når en pasient kommer med angst, uro, skjelvende hender, søvnproblemer, svetting og hjertebank, synes det som om det er vanskelig å stille spørsmål om pasientens alkoholforbruk. Er veien til Sobril og andre benzodiazepiner mye kortere enn veien til de vesentlige spørsmålene? Og er det enklere å komme med antidepressiver enn å samtale om rus?

Når legen kommer med pillene, er det få rusavhengige som protesterer. Tenk hvor behagelig det er å kunne fortsette med drikkingen og samtidig få piller for angsten, søvnproblemene og de andre psykiske plagene. Enn så lenge, inntil dosene må økes ytterligere.

For en alkoholavhengig finnes det én sikker løsning, og det er å kutte ut alkoholen. Så enkelt, men samtidig så vanskelig. For å komme dit trenger han eller hun å erkjenne problemet sitt, og han eller hun må ta ansvar selv.

Da hjelper det hvis legen har kunnskap om alkoholisme, mot til å snakke med pasienten om rus og evne til å motivere pasienten til å ta grep. Men veien til erkjennelse kan bli mye lengre hvis norske leger opptrer som tilretteleggere for videre misbruk - godt hjulpet av smarte legemiddelfirmaer.

Lars Kittilsen

lars@onesto.as
Lars Kittilsen (f. 1969) er forfatter og tørrlagt alkoholiker. Han har vært journalist og redaktør i 20 år.

Forfatter har fylt ut ICMJE-skjemaet og oppgir ingen interessekonflikter.

\section{Litteratur}

1. Brækhus LA. Pille mot alkoholsug godkjent for bruk i Norge. http://abcnyheter.no/nyheter/helse/ 2013/04/18/pille-mot-alkoholsug-godkjent-bruki-norge (15.3.2015).

2. Drikk mindre. Gjør noe. https://drink-less.com/no/ gjor-noe (15.3.2015).

3. Statistikk fra Reseptregisteret. N07BB05 nalmefen. www.reseptregisteret.no/prevalens.aspx (26.3.2015).

4. Statens legemiddelverk. Begrenset effekt av «alkoholpillen» Selincro. http://legemiddelverket.no/ Nyheter/Andre/Sider/Begrenset-effekt-avalkoholmedisinen-Selincro.aspx (15.3.2015).

Mottatt 21.1. 2015, første revisjon innsendt 15.3. 2015, godkjent 27.3. 2015. Redaktør: Elena Aandstad.

Publisert først på nett. 